\title{
APLIKASI TERAPI 'GUIDED IMAGERY' UNTUK PASIEN ASMA DENGAN STATUS ASMATIKUS PADA UNIT GAWAT DARURAT
}

\author{
Nurma Afiani \\ Prodi Ilmu Keperawatan STIKES Widyagama Husada
}

\begin{abstract}
Asthma is a disease of the respiratory tract that can be caused by multifactor. Psychological stress may be one trigger of asthma attacks. One of the psychological therapies that can be performed on patients with asthma is guided imagery. The method used in this study is a literature review as a basis for research to be conducted. The study of literature shows that there is a positive effect of guided imagery therapy against one of the lung function parameters forced expiratory lung capacity (force expiratory volume / FEV). Complementary therapies guided imagery is in line with medical treatment by other health care team to achieve optimal patient conditions.
\end{abstract}

Keywords: Asthma, Guide Imergy, and Force Expiratory Volume 


\begin{abstract}
ABSTRAK
Asma merupakan suatu penyakit pada sistem pernafasan yang dapat disebabkan oleh multifaktor. Stress psikologis dapat menjadi salah satu pencetus serangan asma. Salah satu terapi psikologis yang dapat dilakukan pada pasien dengan asma adalah guided imagery. Metode yang digunakan dalam penelitian ini adalah literature review sebagai dasar bagi penelitian yang akan dilakukan. Hasil studi literature menunjukkan bahwa terdapat pengaruh positif terapi guided imagery terhadap salah satu parameter fungsi paru yakni kapasitas ekspirasi paksa paru (Force Expiratory Volumel FEV). Terapi komplementer guided imagery dilakukan sejalan dengan terapi medis oleh tim kesehatan yang lain untuk mencapai kondisi optimal pasien.
\end{abstract}

\title{
Kata Kunci : Asma, Guide Imergy, Dan Force Expiratory Volume
}

\section{LATAR BELAKANG}

Gangguan pada sistem pernafasan merupakan salah satu penyakit yang paling banyak diderita oleh masyarakat di negara berkembang seperti Indonesia. Salah satu penyakit pada sistem pernafasan yang paling umum terjadi adalah asma. Data terakhir yang disampaikan oleh Organisasi Kesehatan Dunia (WHO) menunjukkan bahwa jumlah penderita asma di dunia mencapai 300 juta jiwa. Di Indonesia sendiri jumlah penderita asma mencapai 12,5 juta jiwa dan hampir 95\% diantaranya adalah penderita asma tak terkontrol (Dewan Asma Indonesia, 2009).

Asma merupakan suatu penyakit yang sangat kompleks karena meliputi gangguan pada sistem neurologi, immunologi, biokimia, endokrin dan faktor psikologis yang dapat mengakibatkan obstruksi pada jalan nafas (Freeman, 2005). Asma juga merupakan salah satu penyakit yang dapat diakibatkan oleh banyak faktor, salah satunya adalah kondisi psikologis pasien. Stress psikologis yang dialami oleh seseorang dapat mengakibatkan menurunnya daya tahan tubuh seseorang termasuk sistem kekebalan pada jalan nafas (Lahman, 2009).

Setelah diketahui bahwa faktor emosional dapat memicu munculnya serangan asma pada seseorang, maka diperlukan suatu terapi psikologis yang dapat mempengaruhi aktivitas jalan nafas melalui proses menyeimbangkan susunan saraf pusat (Lahman, 2009).
Salah satu terapi psikologis yang dapat dilakukan pada pasien dengan asma adalah guided imagery. Imagery merupakan imajinasi dalam pikiran yang menggambarkan pengalaman ataupun angan-angan seseorang. Melalui imagery seseorang dapat menggendalikan fungsi dari sistem tubuh yang tidak dapat dikendalikan dalam kondisi sadar (Rossman, 2000).

Status asmatikus merupakan suatu kondisi dimana terjadi serangan asma berat yang tidak berespon terhadap pengobatan asma pada umumnya. Kondisi ini merupakan salah satu kondisi kegawatan yang dapat mengancam nyawa pasien. Ketika terapi medis tidak mampu memberikan perbaikan pada kondisi pasien, maka terapi alternative seperti guided imagery dapat menjadi salah satu intervensi yang dapat diberikan oleh perawat.

Guided imagery merupakan salah satu terapi komplementer dan termasuk dalam tindakan mandiri profesi keperawatan yang jarang diaplikasikan pada tataran klinik oleh perawat. Padahal terapi komplementer semacam ini dapat memberikan banyak manfaat bagi pasien. Selain itu, dengan mengaplikasikan tindakan mandiri keperawatan maka secara tidak langsung perawat ikut mengembangkan batang tubuh ilmu keperawatan itu sendiri. 


\section{MANFAAT}

Guided imagery telah lama dikenal sebagai salah satu terapi komplementer dalam dunia keperawatan. Terapi ini dapat memberikan banyak manfaat baik bagi pasien, dunia pendidikan keperawatan maupun untuk kemajuan profesi keperawatan di Indonesia.

Asma merupakan suatu penyakit pada sistem pernafasan yang dapat disebabkan oleh multifaktor. Stress psikologis dapat menjadi salah satu pencetus serangan asma. Dengan guided imagery pasien akan diajarkan bagaimana mengendalikan sistem tubuh yang tidak dapat dikendalikan secara sadar (Lahman, 2009).

Terapi guided imagery yang dilakukan pasien dengan asma dapat menyeimbangkan aktivitas sistem saraf otonom pada pasien (Lahman, 2009). Selain itu, terapi guided imagery juga dapat menurunkan kadar serum IgE total dalam tubuh penderita asma (Lahman, 2010). Terapi ini juga murah, aman, efektif, efisien dan dapat dilakukan secara mandiri oleh pasien yang sudah dilatih oleh perawat (Epstein, 2004).

Dewasa ini perawat di Indonesia lebih banyak menjalankan perintah dokter dibandingkan dengan melakukan intervensi mandiri keperawatan. Salah satu intervensi mandiri keperawatan yang sering diabaikan oleh perawat yakni terapi guided imagery.

Aplikasi tindakan mandiri keperawatan oleh perawat dapat menunjukkan bahwa keperawatan adalah sebuah profesi yang memiliki batang tubuh keilmuan yang kuat. Dengan mengaplikasikan terapi modalitas semacam ini menunjukkan profesionalisme seorang perawat, sehingga profesi keperawatan tidak lagi dianggap sebelah mata oleh profesi yang lain.

Selain bermanfaat dalam mengembangkan profesionalisme profesi perawat, aplikasi tindakan mandiri seperti guided imagery juga dapat mengembangkan dunia pendidikan keperawatan. Aplikasi terapi modalitas keperawatan di lingkungan klinik oleh perawat dapat menjadi role model bagi mahasiswa keperawatan.

\section{ANALISIS LITERATUR}

Efek terapi guided imagery pada pasien asma telah banyak diteliti di luar negeri. Salah satu penelitian tersebut yakni 'Functional Relaxation and Guided Imagery as Complementary Therapy in Asthma: A Randomized Controlled Clinical Trial' yang dilakukan oleh Lahmann dan kawan-kawan pada tahun 2009.

Penelitian tersebut dilakukan pada pasien asma ekstrinsik yang dibagi dalam 4 kelompok perlakuan. Perlakuan yang diberikan yakni functional relaxation dan guided imagery yang dilakukan dengan desain penelitian randomized controlled clinical trial. Tujuan dari penelitian ini untuk mengetahui keefektifan terapi functional relaxation dan guided imagery pada pasien asma dewasa.

Peneliti menduga bahwa terapi psikologis dapat mempengaruhi kontrol jalan nafas melalui proses menyeimbangkan aktivitas susunan saraf otonom. Terapi guided imagery membantu seseorang untuk mengendalikan sistem tubuh yang tidak dapat dikendalikan dalam kondisi sadar.

Setelah dilakukan terapi pada keempat kelompok perlakuan didapatkan hasil yang bermakna yakni kelompok yang mendapatkan terapi guided imagery mengalami peningkatan kapasitas ekspirasi paksa paru (Force Expiratory Volume/ FEV).

Dari hasil penelitian diatas dapat diketahui bahwa terdapat pengaruh positif terapi guided imagery terhadap salah satu parameter fungsi paru yakni kapasitas ekspirasi paksa paru (Force Expiratory Volumel FEV). Oleh karena itu terapi guided imagery dianjurkan untuk digunakan sebagai salah satu terapi non-farmakologis pada pasien dengan status asmatikus.

Penelitian yang dilakukan oleh Lahmann dan kawan-kawan ini bukan satu-satunya penelitian yang menunjukkan bahwa terapi komplementer seperti guided imagery memberi efek positif terhadap pasien dengan 
penyakit asma. Beberapa penelitian terkait dengan guided imagery juga menunjukkan bahwa terapi ini dapat menurunkan kadar IgE serum penderita asma (Lahmann, 2010).

Berbagai hasil penelitian tentang pengaruh terapi komplementer guided imagery telah menunjukkan bahwa terapi tersebut secara ilmiah telah terbukti dapat memperbaiki kondisi pasien dengan asma. Sehingga sebaiknya terapi komplementer sebagai intervensi mandiri perawat dilakukan sejalan dengan terapi medis agar dapat memberikan hasil yang optimal pada pasien.

\section{PERAN PERAWAT}

Peran perawat merupakan tingkah laku yang diharapkan oleh orang lain terhadap seseorang sesuai kedudukan dalam sistem, dimana dapat dipengaruhi oleh keadaan sosial baik dari profesi maupun diluar profesi keperawatan yang bersifat konstan. Peran perawat tersebut antara lain sebagai pemberi asuhan keperawatan, advokat, edukator, koordinator, kolaborator, konsultan, dan pembaharuan (Wachid, 2011).

Perawat spesialis sebagai salah satu bagian dari dunia keperawatan memiliki peran yang penting bagi perkembangan ilmu keperawatan. Perawat spesialis adalah seorang sarjana keperawatan yang telah menyelesaikan pendidikan pascasarjana dan melanjutkannya dengan pendidikan ners spesialis (FIK UI, 2011). Sebagai ilmuwan, seorang perawat spesialis memiliki tanggung jawab untuk mengembangkan batang tubuh ilmu keperawatan.

Keperawatan telah diakui sebagai sebuah profesi sejak diketahui adanya batang tubuh ilmu keperawatan didalamnya. Namun sayang, hingga hampir 20 tahun sejak diakuinya keperawatan sebagai sebuah profesi di Indonesia, ilmu keperawatan masih belum banyak berkembang. Belum banyak perawat spesialis yang mengembangkan ilmu keperawatan sesuai spesialisasinya.

Perawat spesialis sudah seharusnya mengembangkan ilmu keperawatan khususnya tindakan mandiri keperawatan seperti terapi komplementer. Melalui penelitian diharapkan ilmu keperawatan semakin berkembang seiring perkembangan teknologi dan informasi.

Salah satu terapi komplementer yang belum banyak menarik perhatian perawat spesialis adalah terapi guided imagery. Peran perawat spesialis yang dapat dilakukan terkait terapi tersebut antara lain sebagai care giver, collaborator dan researcher.

Peran sebagai care giver dapat ditunjukkan dengan mengaplikasikan terapi guided imagery pada pasien dengan status asmatikus. Terapi komplementer seperti guided imagery dilakukan sejalan dengan terapi medis melalui proses kolaborasi dengan tenaga kesehatan yang lain merupakan aplikasi peran perawat sebagai collaborator. Sedangkan peran perawat sebagai researcher ditunjukkan dengan terus melakukan penelitian dalam rangka mengembangkan terapi guided imagery sebagai terapi komplementer pada pasien asma dengan status asmatikus.

\section{CLINICAL SIGNIFICANT}

Asma merupakan suatu penyakit pada sistem pernafasan yang dapat disebabkan oleh multifaktor, seperti infeksi, perubahan kondisi lingkungan maupun kondisi psikologis seseorang. Asma tidak dapat disembuhkan tetapi dapat dimanagemen dengan baik agar tidak menimbulkan keluhan pada pasien.

Keberhasilan managemen asma bervariasi pada setiap orang tergantung pada faktor predisposisi genetik, kerentanan terhadap faktor alergen, kondisi fisik dan psikis, dan usia (Freemann, 2005). Oleh karena itu terapi pada pasien dengan asma bersifat individual terkait dengan faktor pencetus pada tiap individu yang berbedabeda.

Pasien dengan asma dapat berada dalam kondisi gawat darurat jika dinyatakan dalam kondisi status asmatikus. Status asmatikus merupakan suatu eksaserbasi akut dari asma 
yang tidak berespon terhadap pengobatan awal bronkodilator. Status asmatikus dapat bervariasi dari yang ringan sampai berat, yaitu bronkospasme, inflamasi saluran pernafasan, dan sumbatan oleh mukus yang dapat mengakibatkan gangguan pernafasan, retensi karbondioksida, hipoksemia dan gagal nafas (Somantri, 2009).

Pasien asma dengan status asmatikus dapat berada dalam kondisi gawat darurat karena tidak berespon terhadap pengobatan awal bronkodilator. Dalam kondisi seperti ini diperlukan suatu terapi komplementer yang dilakukan sejalan dengan terapi medis. Salah satu terapi komplementer yang dapat digunakan adalah terapi guided imagery. Dengan guided imagery seseorang akan dipandu oleh perawat untuk dapat mengendalikan sistem tubuh yang tidak dapat dikendalikan dalam kondisi sadar (Rossmann, 2000).

Kolaborasi antara terapi medis dengan terapi komplementer yang dilakukan oleh tim medis diharapkan dapat meningkatkan kualitas layanan kepada pasien. Dan pada akhirnya diharapkan kolaborasi kedua terapi tersebut dapat meningkatkan angka kesembuhan pada pasien.

\section{CLINICAL APLICABILITY}

Terapi guided imagery merupakan suatu terapi komplementer keperawatan yang tidak dapat berdiri sendiri tanpa terapi medis. Aplikasi terapi ini pada pasien dengan status asmatikus di Unit Gawat Darurat dilakukan seiring sejalan dengan terapi medis.

Pada setting klinik, pasien dengan status asmatikus yang datang ke Unit Gawat Darurat harus mendapatkan terapi oksigenasi, beta-agonis inhalasi, kortikosteroid dan kolinergik (NAEPP, 2010). Setelah prinsip A, B, C (airway, breathing dan circulation) dari pasien teratasi maka terapi guided imagery dapat dilakukan pada pasien.

Dengan terapi guided imagery pasien akan dibimbing oleh perawat untuk berimajinasi secara visual tentang sistem pernafasannya. Beberapa tahap yang dilakukan dalam terapi guided imagery yakni: 1) Tahap pertama, pasien diinstruksikan untuk berimajinasi tentang suatu hal yang menyenangkan bagi pasien disertai dengan teknik nafas dalam secara santai; 2) Tahap kedua, diawali dengan penjelasan singkat mengenai konsep alergi dan mast sel, dilanjutkan dengan latihan berimajinasi tentang cara kerja mast sel terkait reaksi hypersensitive pada saluran nafas; 3) Tahap ketiga, berfokus pada persepsi sehat pasien, seperti berimajinasi untuk memiliki kondisi fisik yang lebih baik ; 4) Tahap terakhir, merupakan pengulangan langkah-langkah yang dilakukan pada tiap tahap terapi yang telah disebutkan sebelumnya (Lahmann, 2009).

\section{KESIMPULAN}

Asma merupakan salah satu penyakit yang dapat diakibatkan oleh banyak faktor, salah satunya adalah kondisi psikologis pasien. Salah satu terapi psikologis yang dapat dilakukan pada pasien dengan asma adalah guided imagery.

Berdasarkan hasil penelitian diketahui bahwa terapi guided imagery yang dilakukan pada pasien asma dapat meningkatkan kapasitas ekspirasi paksa paru (Force Expiration Volume/ FEV) serta dapat menurunkan kadar IgE dalam serum.

Guided imagery sebagai salah satu intervensi mandiri perawat dapat diaplikasikan pada pasien dengan status asmatikus di Unit Gawat Darurat. Kolaborasi antara terapi medis dengan terapi komplementer yang dilakukan oleh tim medis diharapkan dapat meningkatkan kualitas layanan kepada pasien.

\section{SINOPSIS PENELITIAN}

Penelitian ini akan dilakukan pada pasien dengan penyakit asma dengan kondisi status asmatikus yang datang ke Unit Gawat Darurat (UGD). Sampel dipilih secara simple random sampling. Pasien akan diterapi 'guided imagery' saat mengalami serangan asma. Terapi 'guided imagery' akan dilakukan seiring dengan terapi medis yang diberikan pada 
pasien. Peneliti akan membandingkan perbaikan kondisi pasien antara pasien yang mendapatkan terapi tambahan 'guided imagery' dan pasien yang hanya mendapatkan terapi medis. Perbaikan kondisi pasien dilihat melalui perbaikan frekuensi nafas, upaya nafas, kedalaman nafas dan saturasi oksigen.

\section{DAFTAR PUSTAKA}

DAI (Dewan Asma Indonesia). (2009). Penderita Asma di Indonesia 12,5 juta orang. Diakses $28 \quad$ Maret 2012. http://nasional.lintas.me/article/tribunbata m.co.id/Penderita Asma di Indonesia 12 5 Juta Orang/1.

Epstein, P, H. J., EAM, B., C., B., M, M., KP, B., et al. (2004). A pilot study of mindbody changes in adults with asthma who practice mental imagery. Alternative Therapies in Health and Medicine, 10(4), 6671.

Freeman, L. W., \& Welton, D. (2005). Effects of Imagery, Critical Thinking, and Asthma Education on Symptoms and Mood State in Adult Asthma Patients: A Pilot Study. The Journal of Alternative and Complementary Medicine, 11(1), 57-68.

International Office Fakultas Ilmu Keperawatan Universitas Indonesia. (2011).

Lahman, C., Nickel, M., Schuster, T., Sauer, N., Ronel, J., Noll-Hussong, M., et al. (2010). Effects of Functional Relaxation and Guided Imagery on IgE in Dust-Mite Allergic Adult Journal of Nervous and Mental Disease, 198(2), 125-130.

Lahman, C., Nickel, M., Schuster, T., Sauer, N., Ronel, J., Noll-Hussong, M., et al. (2009). Functional Relaxation and Guided Imagery as Complementary Therapy in Asthma: A Randomized Controlled Clinical Trial. Psychotherapy and Psychosomatics, 78, 233-239.

National Asthma Education and Prevention Programm (NAEPP) of America Expert Panel. (2010).
Rossman, M. L. (2000). Guided Imagery for Self Healing: an essential for anyone seeking wellness. Canada: Publishers Group West.

Wachid, Abdul. (2011). Peran dan Fungsi Perawat.

http://www.prasko.com/2011/05/perandan-fungsi-perawat.html. diakses 29 April 2012 pukul 17.00 WIB.

Somantri, Irman. (2009). Asuhan Keperawatan pada Klien dengan Gangguan Sistem Pernafasan. Penerbit Salemba Medika: Jakarta. 